\title{
sciendo
}

UDK: 338.532.4:336.71

DOI: $10.2478 / j c b t p-2022-0005$

Journal of Central Banking Theory and Practice, 2022, 1, pp. 105-129

Received: 20 August 2020; accepted:09 March 2021

Emna Trabelsi ${ }^{*}$

\section{Macroprudential Transparency and Price Stability in Emerging and Developing Countries}

${ }^{*}$ Departement of Quantitative Methods, University of Sousse, Tunisia, Social and Economic Policy Analysis Laboratory, Tunis, Tunisia

E-mail: emna.trabelsi2007@yahoo.fr

\begin{abstract}
One of the focuses of recent literature has been the macroeconomic effects of macroprudential policy instruments. The innovation of this paper is that it studies the effects of transparent macroprudential policies on price stability. The results presented herein provide the first empirical evidence that macroprudential transparency can aid to achieve stable inflation in emerging and developing countries. The effect is necessarily transmitted through reduced occurrence of banking crises. We also record a particular advantage of macroprudential transparency for non-inflation targeting countries. Overall, the results are robust to the use of two proxies of price stability.
\end{abstract}

Keywords: macroprudential transparency, price stability, banking crisis, dynamic panel, mediation, bootstrapping.

JEL Classification: C33, E31, E52, E58.

\section{Introduction and review of literature}

Price stability has been a long-standing topic of many research papers for its contribution to monetary policy effectiveness. Keeping inflation stable has been and is always the ultimate objective of central banks and academic research has been devoted to analyze its factors and determinants over a range of economies. Strategies to stabilize inflation include adoption of inflation targeting regime (see Ball and Sheridan, 2005; Akram and Eitrheim, 2008; Svensson, 2010; Aguir, 2018; Güler, 2021, etc.), more independent and accountable central banks (e.g., Temple, 1998; Neyapti, 2004; Jàcome and Vàsquez, 2008; Klomp and de Haan, 2010; 
Agoba, Abor, Osei and Sa-Aadu, 2017; Nurbayev, 2018; etc.), tight fiscal policy and better quality of institutions (see Özsahin and Üçler, 2017; Montes and da Cunha Lima, 2018; Nurbayev, 2018). However, since the latest global financial crisis, worldwide central banks have been pledged to embrace financial stability beyond their standard goal of monetary stability, implying the implementation of macroprudential regulation in order to mitigate financial vulnerabilities and ensure the well-functioning of financial systems. Policymakers believe that macroprudential in addition to monetary policy instruments may basically restrain fiscal imbalances (see Borio and Shim, 2007; Borio and Drehmann, 2009). Empirical works such as Claessens, Ghosh, Swati and Mihet (2013), Cerutti, Claessens \& Laeven (2017) and Akinci and Olmstead-Rumsey (2018) also scrutinize the effectiveness and efficacy of macroprudential instruments in limiting and mitigating excessive credit growth, especially in emerging countries. Bruno, Shim andShin (2017) find that the banking sector and bond capital flow management policies are successful in slowing down banking and bond inflows. Tillmann (2015) shows that loan-to-value ratios reduce credit growth and house prices in Korea. Macroprudential tools have also their beneficial effects on economic growth. For instance, Boar, Gambacorta, Lombardo andda Silva (2017) document less volatility in GDP growth for countries that use macroprudential policies, while Bergant, Grigoli, Hansen \& Sandri (2020) find that macroprudential regulation alleviate the effects of global financial shocks on economic growth of emerging markets and thus improves macroeconomic stability. ${ }^{1}$ Only recently has the relationship between price stability and macroprudential policy become the flavour of modern research. The general consensus is, however, mixed. For example, Akram (2014) finds that bank capital requirements have weak effects on macroeconomic variables by using quarterly data on Norway. With a dynamic stochastic equilibrium model, Tayler and Zilberman (2014) argue that countercyclical bank capital regulation is more effective than monetary policy in promoting price and overall macroeconomic stability, while Glocker and Towbin (2015) find that a tightening increase in reserve requirements leads to an increase in the price level in Brazil. Kim and Mehrotra (2018) show that changes in macroprudential policy measures may have negative effects on inflation. Now the effects of variations in loan-to-value ratios on inflation are negligible according to Richter, Schularick \& Shim (2019).

Although this work complements the existing literature, the line of reasoning differs from the papers above because here we do not focus on the macroeco-

\footnotetext{
1 For an overview of literature, see Lim, Costa, Kongsamut, Otani, Saiyid and Wu (2011), Galati and Moessner (2013, 2018), Dumičić (2017) and Araujo, Patman, Popescu, Valencia and Yao (2019).
} 
nomic effects of macroprudential instruments, but on the effect of transparency of macroprudential policy on price stability. Previous works establish that central banks with a higher degree of monetary transparency might enjoy economic benefits such as lower inflation expectations (e.g., van der Cruijsen, Carin and Demertzis, 2007) or inflation persistence (see van der Cruijsen, Eijffinger and Hoogduin, 2010; Dincer and Eichengreen, 2014; Trabelsi, 2016) although theory shows that higher transparency is not always good for social welfare (see Morris and Shin, 2002; Cukierman, 2009). Other papers focus on the impact of transparent fiscal policies on inflation in level and expectation (e.g., Hameed, 2006; Montes and da Cunha Lima, 2018). Overall, both monetary and fiscal transparency yield positive impacts on economy. Can the same be said for macroprudential transparency? This is the central question of the current study.

Considering macroprudential transparency as a potential determinant of inflation is definitely a new contribution to the literature. Our empirical work is particularly rooted as the earlier research fails to find a clear relationship between macroprudential instruments and inflation. Additionally, we are the first to use a macroprudential transparency index taken from Horváth and Vaško (2016). Our analysis is founded on the premise that a more transparent macroprudential policy induces more stable financial systems. Hence, macroprudential transparency is seen as a crisis preventive tool. The financial crisis that erupted in 2008, in turn, pushed inflation to higher levels (see, for instance, Jácome and Vásquez, 2008; Adeleke and Ogebe, 2013; Montes and da Cunha Lima, 2018; Nurbayev, 2018; etc.). Thus, we hypothesize that communicating about potential threats to financial systems through publishing financial stability reports directly and indirectly stabilizes inflation by reducing the occurrence of banking crises. Interestingly, we also record a beneficial effect of macroprudential transparency for non-inflation targeting countries.

To our knowledge, our paper is the first attempt to evaluate the effect of macroprudential transparency on price stability. Furthermore, we provide the first empirical evidence that emerging and developing countries can benefit from increasing macroprudential transparency to yield more stable inflation rates. Our results are robust for using two measures of inflation.

The rest of manuscript is organized as follows. Section 2 reviews the effects of macroprudential policy. Section 3 describes data and methodology. We expose the results in Section 4 and Section 5 concludes. 


\section{Empirical evidence on the effects of macroprudential transparency}

Quantifying the impact of macroprudential transparency is still in its infancy. This fact is mainly due to the lack of reliable measures of macroprudential transparency. The few existing measures especially target the financial stability reports (FSRs). To our knowledge, Sotomska-Krzysztofik and Szczepanska (2006) are the pioneers of the first index of macroprudential transparency calculated on a sample of 35 central banks. Their index is the sum of 10 components related to the goal of central banks and its declaration, publication of FSRs and the frequency of their publications, information about crisis management, information about the lender of the last resort, information about conditions of emergency liquidity assistance, press releases, speeches and the display of issues about financial stability on central banks' websites. A composite index of quality rating is issued by Čihák, Muñoz, Teh Sharifuddin and Tintchev (2012) based on financial stability reports of 44 countries. Whether a country publishes FSRs or not does seem to mitigate the financial risks, but a high FSR quality rating reduces the occurrence of banking crisis and stock market volatility. Born, Ehrmann and Fratzscher (2014) focus on the content and timeline of the financial stability reports as well as the interviews/speeches by central bank governors on a sample of 37 central banks over the period 1996 - 2009. They find that communicating through FSRs significantly reduces stock market volatility especially when assessments tend to be optimistic, while market returns respond to speeches/interviews during crisis times. Horváth and Vaško (2016) build an index of central bank financial stability transparency for 100 countries by summing 11 items that include the publication, the frequency and the coverage of FSRs. Each item is measured on a $0-1$ scale. The final score ranges between 0 (no transparency) and 11 (maximum transparency). They find that increasing macroprudential transparency is beneficial to financial stability until a certain threshold for the entire sample of countries.

\section{Data and econometric model}

\subsection{Data}

We use an unbalanced panel of 190 emerging and developing countries as classified by the International Monetary Fund (IMF). The choice of this class of economies is motivated by the effective use of macroprudential policies in those economies relative to advanced ones (see Borio and Shim, 2007; Lim et al., 2011; Cerutti et al., 2017). The period of investigation spans from 1998 to 2015. Due to missing 
data, we end with trimmed samples. Our dependent variable is the rate of inflation taken from the World Bank's World Development Indicators Database. In this sub-section, we describe country-level macroeconomic, structural and institutional variables that earlier literature identified to be potential determinants of inflation in addition to our variable of interest.

Macroprudential transparency. We select the variable of interest from Horváth and Vaško (2016) because the index is freely available for a large cross-sectional unit and over a reasonable timeline. Figure 1 represents the yearly average of macroprudential transparency scores across countries. We clearly see an upward trend which suggests that emerging and developing countries have incentives to increase the transparency of macroprudential policies.

Real GDP per capita. The natural logarithm of real GDP per capita is available at the World Development Indicators Database. The relationship between income and inflation is bidirectional according to literature. In our paper, we hypothesize that real GDP per capita negatively causes inflation. Including that variable as a factor of inflation is frequent in many papers (e.g., Temple, 1998; Aisen and Veiga, 2006; Klomp and de Haan, 2010; Samimi, Ghaderi, Hosseinzadeh and Nademi, 2011; Agoba, Abor, Osei and Sa-Aadu, 2017; Nurbayev, 2018).

Trade openness. The sum of exports and imports of goods and services as a share of GDP is selected from the World Development Indicators Database.

Central bank independence. The relationship between central bank independence and inflation is well discussed in literature. While in some papers, more independence reduces inflation, other works are not conclusive about the sign and/or its significance (see Loungani and Sheets, 1997; Temple, 1998; Neyapti, 2004; Jácome and Vásquez, 2008; Klomp and de Haan, 2010; Agoba et al., 2017; Nurbayev, 2018). We select the measure of Garriga (2016) who provides data for 182 countries under the period 1970-2012. We use the index of Garriga instead of the measure proposed by Dincer and Eichengreen (2010) because the former is available on a longer timeline.

Political stability, corruption and rule of law. We gather the institutional determinants of inflation from the World Governance Indicators database, originally developed by Kaufmann, Kraay and Mastruzi (2009). Each score ranges between -2.5 and 2.5. Examples of papers including institutional factors of inflation encompass Aisen and Veiga (2006), Montes and da Cunha Lima (2018) and Nurbayev (2018), etc. 
Figure 1: Evolution of the average of the index of macroprudential transparency over time

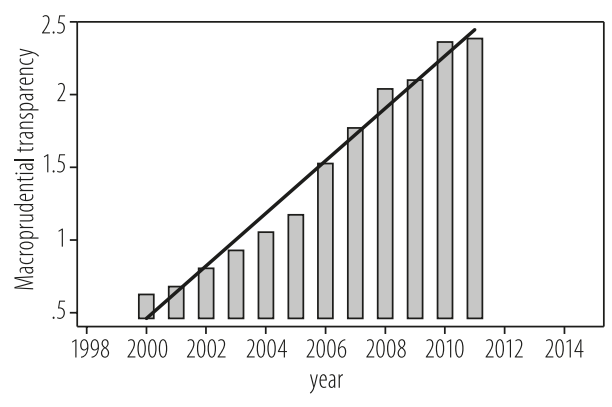

Source: Author
External debt. We use the external debt as a percentage of GNI from the World Development Indicators Database. Klomp and de Haan (2010) find that more external debts cause inflationary pressures on a sample of 100 countries.

Government size. This measure is defined as the general government final consumption expenditures as a share of GDP and obtained from the World Development Indicators Database. On a sample of 42 countries, King and Ma (2001) and Neyapti (2004) shows that government size is likely to increase the rate of inflation.

Inflation targeting. Whether a country adopts inflation targeting or not matters for stabilizing inflation. The variable is a dummy that takes one starting from the year of adoption and zero otherwise. Information about the exact year of inflation targeting adoption is obtained from the IMF and Roger (2010).

Banking crisis. Accounting for a major event such as a financial crisis is mandatory in our model since inflation in many countries has shifted upward in 20072009. The banking crisis dummy is obtained from Laeven and Valencia (2013).

\subsection{Econometric model}

We estimate a standard dynamic panel given by the following equation

$$
\mathrm{y}_{\mathrm{it}}=\alpha \mathrm{y}_{\mathrm{it}-1}+\boldsymbol{\Psi}_{\text {it }}^{\prime} \beta+\mu_{\mathrm{i}}+\delta_{\mathrm{t}}+\varepsilon_{\mathrm{it}},|\alpha|<1
$$

where $\mathrm{y}_{\mathrm{it}}$ is the inflation rate, $\boldsymbol{\Psi}$ is a vector of the macroprudential transparency index plus a set of control variables as specified in the previous sub-section, $\mu_{\mathrm{i}}, \delta_{\mathrm{t}}, \varepsilon_{\mathrm{it}}$ are the individual-specific effects, the time effects, and the idiosyncratic error term, respectively. The subscripts $i$ and $t$ denote the cross-sectional unit and the time dimension, respectively. The choice of the estimation method is an important matter when the model includes a lagged dependent variable because $y_{i t-1}$ is necessarily correlated with the country-fixed effects and this correlation raises an endogeneity bias. Methods such as the Ordinary Least Square (OLS) or the Within estimator are not appropriate in such a case (see Nickell, 1981). 
Regressors contained in the vector $\boldsymbol{\Psi}$ can also be potentially endogenous. The General Method of Moments (GMM) is suitable to overcome this problem. Firstdifferencing Eq. (1) was proposed by Arellano and Bond (1991) to get rid of the fixed effects $\mu_{\mathrm{i}}$ and then using deeper lags of the first-differenced endogenous variables as instruments. Mathematically, this implies the Eq. (2) below

$$
\Delta y_{i t}=\alpha \Delta y_{i t-1}+\Delta \Psi^{\prime}{ }_{i t} \beta+\Delta \delta_{t}+\Delta \varepsilon_{i t}
$$

In the case of a finite sample just as ours, the difference-GMM estimator of Arellano and Bond (1991) might perform poorly. Arellano and Bover (1995) and Blundell and Bond (1998) recommend the system-GMM. The latter is consistent for samples with large cross-sectional units and small-time dimension. We call for the Windmeijer finite sample correction by applying the two-step system-GMM estimation with robust standard errors (Windmeijer, 2005) in order to get more efficient standard errors. Since our panel has missing data, we use the forward orthogonal deviation to maximize the sample size (see Baum, 2013). We use the lag restriction and replace the "GMM-style" instruments with their principal components in order to reduce the instrument count (see Kapetanios and Marcellino, 2010; Bai and Ng, 2010; Mehrhoff, 2009). Finally, all variants of Eq. (1) are estimated with 'xtabond2' routine available from Stata and are accompanied with the essential diagnostic tests as requested by Roodman (2009a, b), namely the number of instruments and the respective p-values of the first-order serial correlation (AR1), the second order serial correlation (AR2) and of the Hansen test of overidentifying restrictions (Hansen, 1982) are computed in the last lines of the output tables.

\section{Results and discussion}

Figure 2 illustrates the triangular relationship between macroprudential transparency $(\mathrm{X})$, banking crisis $(\mathrm{M})$ and inflation $(\mathrm{Y})$. The mediated or indirect effect is quantified by the product $a b$. Thus, our goal is to empirically test our argument through the following hypothesis.

\section{Hypothesis 1. More transparent} macroprudential policies stabilize inflation directly and indirectly by mitigating the occurrence of banking crisis.

Figure 2: Simple mediation analysis

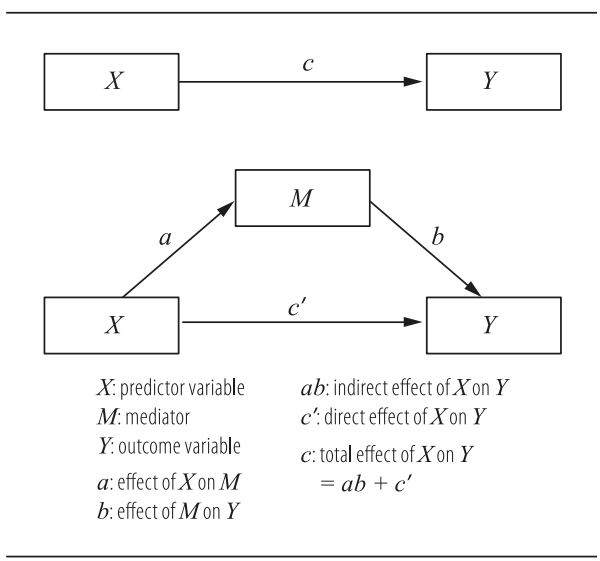

Source: Preacher and Hayes (2004) 


\subsection{Macroprudential transparency and banking crisis}

To test Hypothesis 1, in the first step, we test the path (a). In other terms, we need to see whether macroprudential transparency reduces the occurrence of banking crisis. To do so, we estimate a panel logit model by following Horváth and Vaško (2016) but with the difference that we assume a linear relationship between both variables. Formally, the panel logistic regression has the following representation

$$
\log \left(\frac{P\left[\text { Bcrisis }_{\text {it }}=1 \mid \mathbf{X}\right]}{1-P\left[\text { Bcrisis }_{\text {it }}=1 \mid \mathbf{X}\right]}\right)=\theta_{0}+\mathbf{X}^{\prime} \gamma+\pi_{i}+\epsilon_{i t}
$$

where $\mathrm{X}, \pi_{i}, \epsilon_{i t}$, are the vector of regressors, the individual fixed effects and the idiosyncratic error term. The results of the multivariate estimations of Eq. (3) are available in Table A.1 in Appendix A.

More transparency in macroprudential policies is beneficial for countries in our sample as it contributes to the reduction of banking crisis occurrence. The coefficient is negative and statistically significant at $10 \%$ controlling for other factors. The result contradicts the one of Horváth and Vaško (2016) who find a non-linear quadratic relationship between their index of macroprudential transparency and banking crisis dummy. In their study, macroprudential transparency is beneficial up to a certain value, but we conjecture this result to the use of a mix sample of advanced and emerging and developing countries.

\subsection{Macroprudential transparency and inflation}

In the second step, we conduct panel regressions to verify path (c) (Without mediator) and paths (b) and (c') (With mediator). In other terms, we ask whether macroprudential transparency, by mitigating the occurrence of banking crisis, can allow for better monetary conditions such as stabilizing inflation. The related results are available in Table 1 and suggest that the index of macroprudential transparency loads statistically significant. Particularly, the associated coefficient is negative as expected with magnitude ranging over [-1.018, -0.514]. Meanwhile, the last lines of Table 1 indicate that all tests meet the diagnosis requirements mentioned in sub-section 3.2. Thus, they approve the validity of our dynamic panel estimations. Real GDP per capita (in log) and the index of central bank independence are not statistically significant and end with a wrong sign most of the times. The latter result should not be surprising because earlier studies such as Cukierman, Webb and Neyapti (1992), Campillo and Miron (1997), King and Ma (2001), and Neyapti (2004) find that central bank independence matter for rich countries whose inflation is lower than $20 \%$ and when it is accompanied by or interacted with the tax centralization variable. Openness to trade economically matter for inflation, but 
it is statistically significant only in column 6. Political stability, rule of law and corruption deterrence fight inflationary pressures, but we find that only the first institutional factor effectively causes low inflation. This result is consistent with the findings of Temple (1998), Aisen and Veiga (2006), Klomp and de Haan (2010), Montes and da Cunha Lima (2018) and Nurbayev (2018).

Now controlling for the banking crisis dummy supplies two noteworthy results: First, the inflation goes upwards as the coefficient on the dummy crisis is positive and statistically significant (see columns 7-12). Second, macroprudential transparency still appears as the leading determinant of inflation, but the size effect falls a bit. These results suggest that there is some form of mediation. Particularly, macroprudential transparency has a direct and an indirect effect on inflation and the indirect effect is likely to be transferred by the occurrence of banking crisis dampening. However, to ensure that the indirect is really effective, we need to complement the panel regressions by a separate mediation analysis (see sub-section 4.3). ${ }^{2}$

Next, we carry out a robustness check by substituting the inflation rate with the inflation, GDP deflator. The related results appear in Table 2. Macroprudential transparency index exhibits again a negative and a statistically significant coefficient. A one-unit increase in the score drops the inflation rate by no more than 1.6 percentage units (see columns 1-4). Turning to the controls, real GDP per capita and government consumption fail to load statistically significant although they have the expected signs most of the times. The results related to the institutional determinants are promising. Indeed, political stability, rule of law and corruption have their expected signs and are statistically significant. Countries with better quality of institutions enjoy lower levels of inflation and more stable prices. Once we control for banking crisis, the size effect of macroprudential transparency decreases a bit but still exhibits a negative and a statistically significant coefficient. Banking crisis dummy is also significant and positive, suggesting that macroprudential transparency is likely to exercise a direct and an indirect effect on inflation, GDP deflator through limiting the occurrence of banking crisis and ensuring more stable financial systems.

Finally, the diagnostic tests at the bottom of Table 2, namely, the first order serial correlation (AR1), the second order serial correlation (AR2) and the Hansen test, indicate that all estimations are carried out with carefulness.

2 At our discretion, we also controlled for the exchange rate regime. The associated result is always insignificant. The finding supports the results of Campillo and Miron (1997) and King and Ma (2001). Both papers show that exchange rate regime is not an important factor of inflation. We choose not to report our result for the purpose of concise presentation, but it is available upon request. 


\subsection{Does macroprudential transparency make a difference in non-inflation targeting countries?}

Our previous empirical analysis suggests that emerging and developing countries with higher degrees of macroprudential transparency benefit from lower inflation rates. However, we need to assess whether higher transparency of macroprudential policies can induce better inflation performance for non-inflation targeting countries. Figure 3 clearly shows that both inflation-targeting and non-inflation targeting countries experienced reductions in the rate of inflation. Furthermore, both line plots become close to each other starting from 2009. This suggests that targeting low inflation may not be the sole or the best development strategy for emerging and developing countries (see Anwar, Chowdhury \& Islam, 2011). To put the benefits of macroprudential transparency in perspective, we replicate the panel estimations on the sample of non-inflation targeting countries. Columns 1-7 in Table A.2 in Appendix A indicate that the score of macroprudential transparency appears again as the leading determinant of the inflation rate with negative and statistically significant coefficient. Banking crisis dummy enters Eq. (1) significantly with a positive sign as expected, but the coefficient on macroprudential transparency/though negative either decreases in terms of magnitude

Figure 3: Evolution of the average of inflation over time in inflation-targeting and non-inflation targeting countries

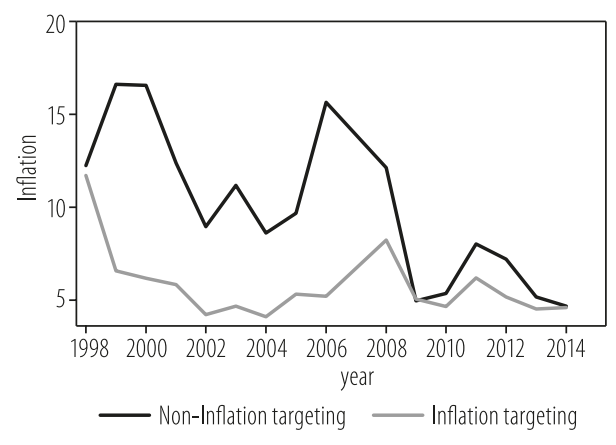

Source: Author or loses its statistical significance (see columns 10-11). This implies that there some form of mediation occurred through the banking crisis dummy. If we substitute the inflation rate with the inflation, GDP deflator, we obtain qualitatively similar results (see Table A.3). However, we note an improvement in institutional determinants' behaviour, namely higher political stability, control of corruption and rule of law economically and significantly decrease the rate of inflation, GDP deflator. ${ }^{3}$ Meanwhile, the diagnostic tests in the last lines of Tables A.2-A.3 validate all estimations.

\footnotetext{
3 At our discretion, we looked at the effect of macroprudential transparency on inflation in inflation targeting countries. The results fail to detect any statistically significant impact of macroprudential transparency. The related results are not reported for the purpose of concise presentation, but they are available upon request from the author.
} 


\subsection{Simple mediation analysis results}

The simple mediation model consists of estimating seemingly unrelated regressions (SUREG) that take the following expression

$$
\left\{\begin{array}{l}
\mathrm{M}=\alpha+a \mathrm{X}+\gamma Z+\varepsilon \\
\mathrm{Y}=\beta+b \mathrm{M}+c^{\prime} \mathrm{X}+\epsilon
\end{array}\right.
$$

where $\mathrm{M}, \mathrm{X}, \mathrm{Z}$ and $\mathrm{Y}$ are again the mediator, the predictor, the covariate(s) and the outcome variable, respectively. According to the above model, the product $a b$ accounts for the so-called indirect effect. The simple mediation, in our case, captures the path Macroprudential transparency $(\mathrm{X}) \rightarrow$ Banking crisis $(\mathrm{M}) \rightarrow$ Inflation (Y). Since the mediation analysis requires independent observations, we average data over the period of investigation to obtain cross sectional data. In this case, banking crisis is interpreted as the frequency of times a crisis occurs in a country. Whether there is a mediation or not, we use the bootstrapping approach for the coefficients of the SUREG model as recommended by Preacher and Hayes (2008). Hence, we need to report the point estimate, quantified by the product $a b$, the standard error and the associated bootstrapped confidence intervals. From the output of Table 3, the point estimate is 0.191 , the standard error is valued at 0.150 , the bias corrected and accelerated confidence intervals are $(0.007$ to 0.502$)$ and (0.003 to 0.491$)$, respectively. As zero does not lie in the respective $90 \%$ confidence intervals, we can infer significant mediation of macroprudential transparency on inflation through the reduction of banking crisis. Along with the panel regression results, we can conclude a partial mediation form (see Zhao, Lynch and Chen, 2010). In other terms, macroprudential transparency has both a direct and an indirect effect on inflation through minimizing the occurrence of banking crises.

If we substitute the dependent variable with inflation, GDP deflator, the simple mediation analysis gives qualitatively the same results. Indeed, the indirect effect of macroprudential transparency is quantified at 0.309 with $90 \%$ percentile, bias corrected and bias corrected and accelerated confidence intervals respectively given by (0.033 to 0.682$),(0.047$ to 0.720$)$ and (0.040 to 0.700$)$. Again, we have the evidence that macroprudential transparency affects directly and indirectly the inflation, GDP deflator through banking crisis reduction. Applying the mediation analysis on non-inflation targeting sample informs us that the indirect effect through banking crisis is statistically significant with $90 \%$ of confidence interval when the dependent variable is the inflation, GDP deflator, but we fail to detect a significant indirect effect of macroprudential transparency when the dependent variable is the inflation rate. 


\section{Conclusion}

History records that inflation might be worrying when countries experience economic and financial recessions. Our paper provides the first empirical evidence that macroprudential transparency could be an essential and useful tool for price stability and that the effect is transferred through mitigating the occurrence of banking crisis. Nevertheless, policymakers around the world should take preventive measures that are not only based on economic and financial criteria, but also on public health threats that can lead to economic shocks. The unprecedented worldwide Covid-19 pandemic is an excellent example that has its consequences on human health as well as on economic conditions. However, accounting for such a major event is left for future research until more data are collected, especially for macroprudential transparency index.

Table 1: Effect of macroprudential transparency on inflation

\begin{tabular}{|c|c|c|c|c|c|c|c|}
\hline & \multicolumn{7}{|c|}{ Without mediator: Path (c) } \\
\hline & (1) & (2) & (3) & (4) & (5) & (6) & (7) \\
\hline Inflation $_{\mathrm{it}-1}$ & $\begin{array}{l}0.372^{* * *} \\
(0.030)\end{array}$ & $\begin{array}{c}0.344^{* * *} \\
(0.017)\end{array}$ & $\begin{array}{l}0.392^{* * *} \\
(0.030)\end{array}$ & $\begin{array}{l}0.395^{* * * *} \\
(0.036)\end{array}$ & $\begin{array}{c}0.389^{* * *} \\
(0.030)\end{array}$ & $\begin{array}{l}0.362^{* * *} \\
(0.044)\end{array}$ & $\begin{array}{l}0.346^{* * *} \\
(0.042)\end{array}$ \\
\hline $\mathrm{MPT}_{\mathrm{it}-1}$ & $\begin{array}{l}-0.514^{*} \\
(0.268)\end{array}$ & $\begin{array}{l}-1.018^{*} \\
(0.554)\end{array}$ & $\begin{array}{c}-1.984^{* *} \\
(0.891)\end{array}$ & $\begin{array}{c}-0.678^{*} \\
(0.400)\end{array}$ & $\begin{array}{l}-0.587^{*} \\
(0.329)\end{array}$ & $\begin{array}{l}-0.646^{*} \\
(0.373)\end{array}$ & $\begin{array}{c}-0.757^{*} \\
(0.453)\end{array}$ \\
\hline Real GDP per capita ${ }_{\mathrm{it}-1}(\mathrm{log})$ & & & $\begin{array}{c}-0.192 \\
(1.558)\end{array}$ & $\begin{array}{l}-0.188 \\
(2.815)\end{array}$ & $\begin{array}{c}1.094 \\
(3.176)\end{array}$ & $\begin{array}{c}0.443 \\
(1.897)\end{array}$ & $\begin{array}{r}1.723 \\
(1.826)\end{array}$ \\
\hline Government consumption $_{\text {it-1 }}$ & $\begin{array}{c}0.057 \\
(0.187)\end{array}$ & & & & & & \\
\hline External debt/GNI & & $\begin{array}{l}0.036^{*} \\
(0.019)\end{array}$ & & & & & \\
\hline \multicolumn{8}{|l|}{ Banking $_{\text {crisis }}{ }_{\mathrm{it}-1}$} \\
\hline $\mathrm{CBI}_{\mathrm{it}}$ & & & $\begin{array}{c}6.571 \\
(4.684)\end{array}$ & & & & \\
\hline Trade $_{\text {it }}$ & $\begin{array}{l}0.023 \\
(0.020)\end{array}$ & $\begin{array}{c}0.006 \\
(0.017)\end{array}$ & & $\begin{array}{l}-0.011 \\
(0.022)\end{array}$ & $\begin{array}{l}-0.007 \\
(0.013)\end{array}$ & $\begin{array}{l}-0.003 \\
(0.031)\end{array}$ & $\begin{array}{c}-0.024^{* *} \\
(0.012)\end{array}$ \\
\hline$P S_{i t-1}$ & $\begin{array}{c}-3.677^{* * *} \\
(1.036)\end{array}$ & $\begin{array}{c}-4.107^{* * *} \\
(1.369)\end{array}$ & & & $\begin{array}{l}-1.617^{*} \\
(0.843)\end{array}$ & & \\
\hline $\mathrm{RL}_{\mathrm{it}-1}$ & & & & & & $\begin{array}{l}-1.793 \\
(3.558)\end{array}$ & \\
\hline$C_{i t-1}$ & & & & & & & $\begin{array}{l}-0.752 \\
(2.630)\end{array}$ \\
\hline Constant & $\begin{array}{c}1.579 \\
(2.892) \\
\end{array}$ & $\begin{array}{c}2.444 \\
(2.137) \\
\end{array}$ & $\begin{array}{c}6.359 \\
(13.194) \\
\end{array}$ & $\begin{array}{c}9.282 \\
(22.800) \\
\end{array}$ & $\begin{array}{c}-2.513 \\
(26.568) \\
\end{array}$ & $\begin{array}{c}1.941 \\
(16.105) \\
\end{array}$ & $\begin{array}{r}-10.103 \\
(15.671) \\
\end{array}$ \\
\hline Noobservations & 813 & 600 & 919 & 905 & 827 & 829 & 829 \\
\hline $\mathrm{N}^{\circ}$ countries & 78 & 57 & 78 & 79 & 79 & 79 & 79 \\
\hline Noinstruments & 69 & 54 & 64 & 63 & 66 & 67 & 58 \\
\hline AR1 (p-value) & 0.020 & 0.033 & 0.003 & 0.006 & 0.017 & 0.018 & 0.016 \\
\hline AR2 (p-value) & 0.313 & 0.149 & 0.719 & 0.431 & 0.394 & 0.554 & 0.686 \\
\hline Hansen test (p-value) & 0.383 & 0.510 & 0.203 & 0.149 & 0.181 & 0.111 & 0.428 \\
\hline
\end{tabular}




\begin{tabular}{|c|c|c|c|c|c|c|}
\hline & \multicolumn{6}{|c|}{ Without mediators: Paths (b) and ( $\left.c^{\prime}\right)$} \\
\hline & (8) & (9) & $(10)$ & (11) & $(12)$ & $(13)$ \\
\hline Inflation $_{\mathrm{it}-1}$ & $\begin{array}{c}0.372^{* * *} \\
(0.026)\end{array}$ & $\begin{array}{l}0.409^{* * *} \\
(0.025)\end{array}$ & $\begin{array}{l}0.379^{* * * *} \\
(0.038)\end{array}$ & $\begin{array}{l}0.378^{* * *} \\
(0.034)\end{array}$ & $\begin{array}{c}0.347^{* * *} \\
(0.039)\end{array}$ & $\begin{array}{c}0.382^{* * * *} \\
(0.035)\end{array}$ \\
\hline $\mathrm{MPT}_{\mathrm{it}-1}$ & $\begin{array}{l}-0.537^{*} \\
(0.316)\end{array}$ & $\begin{array}{c}-1.068^{* *} \\
(0.540)\end{array}$ & $\begin{array}{c}-0.649^{* * *} \\
(0.319)\end{array}$ & $\begin{array}{l}-0.584^{* *} \\
(0.261)\end{array}$ & $\begin{array}{l}-0.526^{*} \\
(0.279)\end{array}$ & $\begin{array}{c}-0.643^{*} \\
(0.358)\end{array}$ \\
\hline Real GDP per capita ${ }_{\mathrm{it}-1}(\mathrm{log})$ & & $\begin{array}{c}0.720 \\
(1.779)\end{array}$ & $\begin{array}{l}-1.029 \\
(2.333) \\
\end{array}$ & $\begin{array}{l}-0.691 \\
(3.223)\end{array}$ & $\begin{array}{c}1.063 \\
(1.644) \\
\end{array}$ & $\begin{array}{c}0.215 \\
(1.742)\end{array}$ \\
\hline Government consumption $_{\mathrm{it}-1}$ & $\begin{array}{c}0.129 \\
(0.234)\end{array}$ & & & & & \\
\hline \multicolumn{7}{|l|}{ External debt/GNI $\mathrm{ut}-1$} \\
\hline 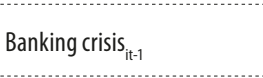 & $\begin{array}{l}5.595^{*} \\
(3.308)\end{array}$ & $\begin{array}{l}7.365^{*} \\
(4.102)\end{array}$ & $\begin{array}{c}7.002^{*} \\
(4.205)\end{array}$ & $\begin{array}{l}6.311^{*} \\
(3.592)\end{array}$ & $\begin{array}{c}6.17^{8^{*}} \\
(3.621)\end{array}$ & $\begin{array}{l}5.844^{*} \\
(3.448)\end{array}$ \\
\hline $\mathrm{CBI}_{\text {it }}$ & & $\begin{array}{c}2.367 \\
(3.096)\end{array}$ & & & & \\
\hline Trade $_{\text {it }}$ & $\begin{array}{c}0.014 \\
(0.014)\end{array}$ & & $\begin{array}{l}-0.004 \\
(0.021)\end{array}$ & $\begin{array}{l}-0.008 \\
(0.023)\end{array}$ & $\begin{array}{l}-0.004 \\
(0.023)\end{array}$ & $\begin{array}{l}-0.007 \\
(0.015)\end{array}$ \\
\hline$P S_{i t-1}$ & $\begin{array}{c}-3.080^{* * * *} \\
(0.931)\end{array}$ & & & $\begin{array}{l}-0.458 \\
(1.362) \\
\end{array}$ & & \\
\hline $\mathrm{RL}_{\mathrm{it}-1}$ & & & & & $\begin{array}{l}-2.864 \\
(3.109)\end{array}$ & \\
\hline $\mathrm{CC}_{\mathrm{it}-1}$ & & & & & & $\begin{array}{l}-1.652 \\
(3.874)\end{array}$ \\
\hline Constant & $\begin{array}{c}4.859 \\
(3.702) \\
\end{array}$ & $\begin{array}{c}-4.801 \\
(14.878)\end{array}$ & $\begin{array}{c}12.048 \\
(17.597) \\
\end{array}$ & $\begin{array}{c}8.101 \\
(26.309)\end{array}$ & $\begin{array}{c}-2.869 \\
(14.366)\end{array}$ & $\begin{array}{c}7.281 \\
(14.153)\end{array}$ \\
\hline Noobservations & 813 & 919 & 905 & 827 & 829 & 829 \\
\hline $\mathrm{N}^{\circ}$ countries & 78 & 78 & 79 & 79 & 79 & 79 \\
\hline$N^{\circ}$ instruments & 75 & 77 & 77 & 77 & 78 & 73 \\
\hline AR1 (p-value) & 0.020 & 0.003 & 0.006 & 0.017 & 0.017 & 0.016 \\
\hline AR2 (p-value) & 0.413 & 0.787 & 0.597 & 0.642 & 0.653 & 0.592 \\
\hline Hansen test ( $p$-value) & 0.451 & 0.249 & 0.335 & 0.310 & 0.249 & 0.356 \\
\hline
\end{tabular}

Robust standard errors in parentheses

${ }^{*} p<0.1,{ }^{* *} p<0.05,{ }^{* * *} p<0.01$

Inflation: inflation rate, MPT: the index of macroprudential transparency, Real GDP per capita (log): The natural logarithm of real GDP per capita, Government consumption: Government consumption as a share of GDP, External debt: the ratio of external debt to GNI, banking crisis: a dummy that takes one if a crisis occurs in a country and 0 otherwise, Trade: The share of imports and exports to GDP, CBI: central bank independence index of Garriga (2016), PS: political stability, RL: rule of law and CC: control of corruption.

AR1, AR2 are the first-order and the second order serial correlation and Hansen is the test of overidentifying restrictions. 
Table 2: Effect of macroprudential transparency on inflation, GDP deflator

\begin{tabular}{|c|c|c|c|c|c|c|c|c|c|c|c|}
\hline & \multicolumn{4}{|c|}{ Without mediator: Path (c) } & \multicolumn{7}{|c|}{ With mediator: Paths (b) and ( $\left.c^{\prime}\right)$} \\
\hline & (1) & (2) & (3) & (4) & (5) & (6) & (7) & (8) & (9) & (10) & (11) \\
\hline $\begin{array}{l}\text { Inflation_GDP } \\
\text { deflator }\end{array}$ & $\begin{array}{l}0.258^{* *} \\
(0.113)\end{array}$ & $\begin{array}{l}0.219^{*} \\
(0.129)\end{array}$ & $\begin{array}{l}0.244^{* *} \\
(0.109)\end{array}$ & $\begin{array}{l}0.248^{* *} \\
(0.119)\end{array}$ & $\begin{array}{l}0.280^{* *} \\
(0.119)\end{array}$ & $\begin{array}{l}0.305^{* * *} \\
(0.106)\end{array}$ & & $\begin{array}{l}0.295^{* *} \\
(0.124)\end{array}$ & $\begin{array}{l}0.241^{*} \\
(0.140)\end{array}$ & $\begin{array}{l}0.201^{*} \\
(0.120)\end{array}$ & $\begin{array}{l}0.226^{*} \\
(0.123)\end{array}$ \\
\hline $\mathrm{MPT}_{\mathrm{it}-1}$ & $\begin{array}{l}-1.530^{* *} \\
(0.770)\end{array}$ & $\begin{array}{c}-1.627^{* *} \\
(0.749)\end{array}$ & $\begin{array}{l}-1.375^{* *} \\
(0.650)\end{array}$ & $\begin{array}{c}-1.406^{* *} \\
(0.584)\end{array}$ & $\begin{array}{l}-0.981^{*} \\
(0.571)\end{array}$ & $\begin{array}{l}-1.507^{*} \\
(0.771)\end{array}$ & & $\begin{array}{l}-1.132^{*} \\
(0.612)\end{array}$ & $\begin{array}{l}-1.746^{* *} \\
(0.704)\end{array}$ & $\begin{array}{l}-1.215^{* *} \\
(0.508)\end{array}$ & $\begin{array}{r}-0.859^{* *} \\
(0.402)\end{array}$ \\
\hline $\begin{array}{l}\text { Real GDP per } \\
\text { capita }_{\text {itt-1 }}(\mathrm{log})\end{array}$ & & $\begin{array}{c}1.818 \\
(1.890) \\
\end{array}$ & $\begin{array}{c}1.411 \\
(1.280)\end{array}$ & $\begin{array}{c}0.900 \\
(1.245)\end{array}$ & & $\begin{array}{c}0.254 \\
(1.357)\end{array}$ & & $\begin{array}{c}0.044 \\
(1.007)\end{array}$ & $\begin{array}{l}-0.623 \\
(1.836)\end{array}$ & $\begin{array}{l}-0.647 \\
(1.747)\end{array}$ & $\begin{array}{l}-0.310 \\
(1.795)\end{array}$ \\
\hline $\begin{array}{l}\text { Government con- } \\
\text { sumption }\end{array}$ & $\begin{array}{c}0.140 \\
(0.498)\end{array}$ & & & & $\begin{array}{c}0.349 \\
(0.648)\end{array}$ & & & & & & \\
\hline Banking $\mathrm{crisis}_{\mathrm{it}-1}$ & & & & & $\begin{array}{l}15.828^{* * *} \\
(6.522)\end{array}$ & $\begin{array}{c}9.115^{*} \\
(5.254)\end{array}$ & & $\begin{array}{l}9.393^{*} \\
(5.355)\end{array}$ & $\begin{array}{l}10.546^{* *} \\
(5.285)\end{array}$ & $\begin{array}{c}9.831^{*} \\
(5.389) \\
\end{array}$ & $\begin{array}{c}5.468 \\
(5.300)\end{array}$ \\
\hline Trade $_{\text {it }}$ & $\begin{array}{c}0.024 \\
(0.033)\end{array}$ & $\begin{array}{c}0.013 \\
(0.040)\end{array}$ & $\begin{array}{l}-0.011 \\
(0.023)\end{array}$ & $\begin{array}{l}-0.000 \\
(0.027)\end{array}$ & $\begin{array}{l}0.003 \\
(0.039)\end{array}$ & $\begin{array}{l}-0.025 \\
(0.018)\end{array}$ & & $\begin{array}{l}-0.022 \\
(0.017)\end{array}$ & $\begin{array}{l}0.018 \\
(0.028)\end{array}$ & $\begin{array}{c}0.023 \\
(0.030)\end{array}$ & $\begin{array}{c}0.016 \\
(0.028)\end{array}$ \\
\hline $\mathrm{CBI}_{\mathrm{it}}$ & & & & & & $\begin{array}{c}3.234 \\
(4.122)\end{array}$ & & & & & \\
\hline$P S_{i t-1}$ & $\begin{array}{l}-5.885^{* * *} \\
(2.272)\end{array}$ & $\begin{array}{c}-5.537^{* * * *} \\
(2.124)\end{array}$ & & & $\begin{array}{l}-4.269^{*} \\
(2.407)\end{array}$ & & & & $\begin{array}{l}-3.936^{* * *} \\
(1.330)\end{array}$ & & \\
\hline $\mathrm{RL}_{\mathrm{it}-1}$ & & & $\begin{array}{r}-4.258^{*} \\
(2.292) \\
\end{array}$ & & & & & & & $\begin{array}{c}-6.562^{* *} \\
(2.799)\end{array}$ & \\
\hline $\mathrm{CC}_{\mathrm{it}-1}$ & & & & $\begin{array}{l}-5.639^{* * *} \\
(2.410)\end{array}$ & & & & & & & $\begin{array}{c}-7.161^{* * *} \\
(2.465)\end{array}$ \\
\hline Constant & $\begin{array}{c}6.451 \\
(8.195) \\
\end{array}$ & $\begin{array}{c}-4.094 \\
(15.760) \\
\end{array}$ & $\begin{array}{c}0.542 \\
(12.040) \\
\end{array}$ & $\begin{array}{c}4.011 \\
(10.447) \\
\end{array}$ & $\begin{array}{c}2.238 \\
(10.129) \\
\end{array}$ & $\begin{array}{c}10.462 \\
(10.741) \\
\end{array}$ & & $\begin{array}{l}11.674 \\
(8.231) \\
\end{array}$ & $\begin{array}{c}5.423 \\
(15.360) \\
\end{array}$ & $\begin{array}{c}13.809 \\
(14.834) \\
\end{array}$ & $\begin{array}{c}10.472 \\
(13.887) \\
\end{array}$ \\
\hline Noobservations & 838 & 855 & 857 & 857 & 838 & 920 & & 936 & 855 & 857 & 857 \\
\hline $\mathrm{N}^{\circ}$ countries & 81 & 81 & 81 & 81 & 81 & 80 & & 81 & 81 & 81 & 81 \\
\hline Noinstruments & 68 & 68 & 68 & 66 & 80 & 74 & & 70 & 80 & 77 & 69 \\
\hline AR1 (p-value) & 0.009 & 0.009 & 0.006 & 0.008 & 0.006 & 0.004 & & 0.005 & 0.009 & 0.007 & 0.007 \\
\hline AR2 (p-value) & 0.694 & 0.719 & 0.662 & 0.723 & 0.733 & 0.261 & & 0.300 & 0.717 & 0.766 & 0.798 \\
\hline $\begin{array}{l}\text { Hansen test } \\
\text { (p-value) }\end{array}$ & 0.230 & 0.084 & 0.228 & 0.110 & 0.257 & 0.065 & & 0.103 & 0.120 & 0.126 & 0.081 \\
\hline
\end{tabular}

Robust standard errors in parentheses

${ }^{*} \mathrm{p}<0.1,{ }^{* *} \mathrm{p}<0.05,{ }^{* * *} \mathrm{p}<0.01$

Inflation_GDP deflator: inflation, GDP deflator, MPT: the index of macroprudential transparency, Real GDP per capita (log): The natural logarithm of real GDP per capita, Government consumption: Government consumption as a share of GDP, banking crisis: a dummy that takes one if a crisis occurs in a country and 0 otherwise, Trade: The share of imports and exports to GDP, CBI: central bank independence index of Garriga (2016), PS: political stability, RL: rule of law and CC: control of corruption.

AR1, AR2 are the first-order and the second order serial correlation and Hansen is the test of overidentifying restrictions. 
Table 3: Cross-sectional mediation analysis

Dependent variable: Inflation

Mediator: Banking crisis

Predictor: Macroprudential transparency

$\begin{array}{rlrr}\text { Bootstrap results } & \begin{array}{l}\text { Number of obs } \\ \text { Replications }\end{array} & \begin{array}{r}79 \\ =\end{array} \\ \text { command: bootmm } \\ \text { bs_1: } \\ \text { r(indbcrisis) }\end{array}$

(P)percentile confidence interval

(BC)bias-corrected confidence interval

(BCa)bias-corrected and accelerated confidence interval

indbcrisis: The indirect effect of macroprudential transparency on inflation through banking crisis.

\section{Table 3: Cont.}

Dependent variable: Inflation, GDP deflator

Mediator: Banking crisis

Predictor: Macroprudential transparency

Bootstrap results

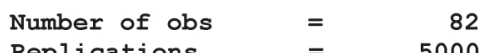

command: bootmm

_bs_1: r(indbcrisis)

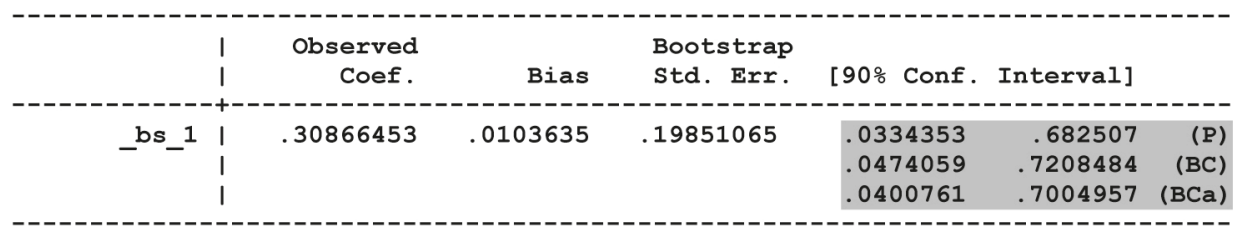

(P) percentile confidence interval

(BC) bias-corrected confidence interval

(BCa) bias-corrected and accelerated confidence interval

indbcrisis: The indirect effect of macroprudential transparency on inflation, gdp defaltor through banking crisis. 


\section{References}

1. Adeleke, A. I., \& Ogebe, J. O. (2013). Banking crises and inflation dynamics in the West Africa Monetary Zone (WAMZ). Journal of Economics and International Finance, 5(6), 225-231.

2. Agoba, A. M., Abor, J., Osei, K. A., \& Sa-Aadu, J. (2017). Central bank independence and inflation in Africa: The role of financial systems and institutional quality, Central Bank Review, 17(4), 131-146.

3. Aguir, A. (2018). Central bank credibility, independence, and monetary policy. Journal of Central Banking Theory and Practice, 7(3), 91-110.

4. Aisen, A., \& Veiga, F.J., (2006). Does Political Instability Lead to Higher Inflation? A panel data analysis. Journal of Money, Credit and Banking, 38(5), 1379-1389.

5. Akinci, O., \& Olmstead-Rumsey, J. (2018). How Effective are Macroprudential Policies? An Empirical Investigation. Journal of Financial Intermediation, 33, 33-57.

6. Akram, Q. F. (2014). Macro effects of capital requirements and macroprudential policy. Economic Modelling, 42, 77-93.

7. Akram, Q. F., \& Eitrheim, Ø. (2008). Flexible inflation targeting and financial stability: Is it enough to stabilize inflation and output? Journal of Banking and Finance, 32(7), 1242-1254.

8. Anwar, S., Chowdhury, A., \& Islam, I. (2011). Inflation targeting in developing countries revisited. VOX CEPR. Available at: https://voxeu.org/ debates/commentaries/inflation-targeting-developing-countries-revisited

9. Arellano, M., \& Bond, S. (1991). Some tests of specification for panel data: Monte Carlo evidence and an application to employment equations. Review of Economic Studies, 58, 277- 297.

10. Arellano, M., \& Bover, O. (1995). Another look at the instrumental variables estimation of error components models. Journal of Econometrics, 68, 29-51.

11. Araujo, J., Patnam, M., Popescu, A., Valencia, F., \& Yao, W. (2020). Effects of Macroprudential Policy: Evidence from over 6,000 Estimates. IMF Working Paper 20/67....

12. Bai, J., \& Ng, S. (2013). Principal components estimation and identification of static factors. Journal of Econometrics, 176(1), 18-29.

13. Ball, L. M., \& Sheridan, N. (2005). Does inflation targeting matter? In the Inflation-Targeting Debate, ed. Ben S. Bernanke and Michael Woodford, 249-76. Chicago and London: University of Chicago Press.

14. Baum, C. F. (2013). Dynamic panel data estimators. Available at: http://fmwww.bc.edu/EC-C/S2013/823/EC823.S2013.nn05.slides.pdf 
15. Bergant, K., Grigoli, F., Hansen, N-J., \& Sandri, D. (2020). Dampening Global financial shocks: Can macroprudential Regulation help (More than capital controls)? IMF Working Paper n¹06.

16. Blundell, R., \& Bond, S. (1998) Initial conditions and moment restrictions in dynamic panel data models. Journal of Econometrics, 87, 115-143.

17. Boar, C., Gambacorta, L., Lombardo, G., \& da Silva, L. P. (2017). What are the Effects of Macroprudential Policies on Macroeconomic Performance? BIS Quarterly Review.

18. Borio, C. \& Drehmann, M. (2009). Assessing the risk of banking crises revisited. BIS Quarterly Review, March, 29-46.

19. Borio, C. and Shim, I. (2007). What can (macro-)prudential policy do to support monetary policy? BIS Working Paper No. 242.

20. Borio, C. and Drehmann, M. (2009). Towards an operational framework for financial stability: "Fuzzy" measurement and its consequences. BIS Working Paper n²84.

21. Born, B., Ehrmann, M., \& Fratzscher, M. (2014). Central bank communication on financial stability. The Economic Journal, 124(577), 701734.

22. Bruno, V., Shim, I., \& Shin, Hyun S. (2017). Comparative Assessment of Macroprudential Policies. Journal of Financial Stability, 28, 183 - 202.

23. Campillo, M., \& Miron, J. A. (1997). Why does inflation differ across countries? In Romer, C. D., Romer, D. H. (Eds.), Reducing inflation: Motivation and Strategy. University of Chicago Press, Chicago, 335-357.

24. Cerutti, E., Claessens, S., \& Laeven, L. (2017). The use and effectiveness of macroprudential policies: New evidence. Journal of Financial Stability, 28, 203-224.

25. Čihák, M., Muñoz, S., Teh Sharifuddin, S., \& Tintchev, K. (2012). Financial stability reports: What are they good for? IMF Working Paper No. 1. Available at: https://www.imf.org/external/pubs/ft/wp/2012/wp1201.pdf

26. Claessens, S., Ghosh, Swati R., \& Mihet, R. (2013). Macro-Prudential Policies to Mitigate Financial System Vulnerabilities. Journal of International Money and Finance, 39, 153-185.

27. Cukierman, A. (2009). The limits of transparency. Economic Notes, 38(1-2), 1-37.

28. Cukierman, A., Webb, S. A., \& Neyapti, B. (1992). Measuring independence of central banks and its effect on policy outcome. World Bank Economic Review, 6, 353-398.

29. Dincer, Nergis N. \& Eichengreen, B. (2014). Central bank transparency and independence: Updates and new measures. International Journal of Central Banking, 10(1), 189-253. 
30. Dumičić, M. (2017). A Brief Introduction to the World of Macroprudential Policy. Journal of Central Banking Theory and Practice, 6(1), 87-109.

31. Galati, G., \& Moessner, R. (2018). What Do We Know About the Effects of Macroprudential Policy? Economica, 85(340): 735-770.

32. Galati, G., \& Moessner, R. (2013). Macroprudential policy- A literature review. Journal of Economic Surveys, 27(5), 846-878.

33. Garriga, Ana C. (2016). Central Bank Independence in the World: A New Dataset. International Interactions, 42 (5), 849-868.

34. Glocker, C., \& Towbin, P. (2015). Reserve Requirements as a Macroprudential Instrument - Empirical Evidence from Brazil, Journal of Macroeconomics, doi: http://dx.doi.org/10.1016/j.jmacro. 2015.02.007

35. Güler, A. (2021). Does Monetary Policy Credibility Help in Anchoring Inflation Expectations? Evidence from Six Inflation Targeting Emerging Economies1. Journal of Central Banking Theory and Practice, 1, 93-111.

36. Hameed, F. (2006). Essays on fiscal transparency and inflation expectations. PhD Dissertation, Johns Hopkins University, 1-170.

37. Hansen, Lars, P. (1982). Large sample properties of generalized method of moments estimators. Econometrica, 50(4), 1029-1054.

38. Horváth, R., \& Vaško, D. (2016). Central bank transparency and financial stability. Journal of Financial Stability, 22, 45-56.

39. Jácome, L. I., \& Vázquez, F. (2008). Is there any link between legal central bank independence and inflation? Evidence from Latin America and Caribbean. European Journal of Political Economy, 24, 788-801.

40. Kapetanios, G., \& Marcellino, M. (2010). Factor-GMM estimation with large sets of possibly weak instruments. Computational Statistics and Data Analysis, 54(11), 2655-2675.

41. Kaufmann, D., Kraay, A., \& Mastruzi, M. (2009). Governance Matters VIII: Aggregate and Individual Governance Indicators, 1996-2008. World Bank Policy Research Working Paper n 4978.

42. Kim, S, \& Mehrotra, A. (2018). Effects of monetary and macroprudential policies - evidence from inflation targeting economies in the Asia-Pacific region and potential implications for China. Journal of Money, Credit and Banking, 50(5), 967-992.

43. King, D., \& Ma, Y. (2001). Fiscal decentralization, central bank independence and inflation. Economics Letters, 72, 95-98.

44. Klomp, J., \& de Haan, J. (2010). Inflation and central bank independence: A meta-regression analysis. Journal of Economic Surveys, 24(4), 593-621.

45. Laeven, L. \& Valencia, F. (2013). Systemic banking crises database. IMF Economic Review, 61(2), 225-270.

46. Lim, C. H., Costa, A., Columba, F., Kongsamut, P., Otani, A., Saiyid, M., Wezel, T., Wu, X., (2011). Macroprudential Policy: What Instruments and 
How to Use Them? Lessons from Country Experiences. IMF Working Papers 11/238, International Monetary Fund. http://www.imf.org/ external/ np/pp/eng/2013/061013c.pdf

47. Loungani, P., \& Sheets, N. (1997). Central bank independence, inflation, and growth in transition economies. Journal of Money, Credit and Banking, 29(3), 381-399.

48. Mehrhoff, J. (2009). A solution to the problem of too many instruments in dynamic panel data GMM. Discussion Paper, Series 1: Economic Studies No. 31. Available at: https://core.ac.uk/download/pdf/6386086.pdf

49. Montes, G. C., \& da Cunha Lima, L. L. (2018). Effects of fiscal transparency on inflation and inflation expectations: Empirical evidence from developed and developing countries. The Quarterly Review of Economics and Finance, 70, 26-37.

50. Morris, S., \& Shin, H. S. (2002). The Social Value of Public Information. American Economic Review, 92, 1521-1534.

51. Nickell, S. (1981). Biases in dynamic panel models with fixed effects. Econometrica, 49(6), 1417-1426.

52. Neyapti, B. (2004). Fiscal decentralization, central bank independence and inflation: a panel investigation. Economics Letters, 82, 227-330.

53. Nurbayev, D. (2018). The rule of law, central bank independence and price stability. Journal of Institutional Economics, 14(4), 658-687.

54. Özsahin, Şe, \& Üçler, G. (2017). The Consequences of Corruption on Inflation in Developing Countries: Evidence from Panel Cointegration and Causality Tests. Economies, 5(4), 1-15.

55. Preacher, K. J., \& Hayes, A. F. (2004). SPSS and SAS Procedures for Estimating Indirect Effects in Simple Mediation Models. Behavior Research Methods, 36(4), 717-731.

56. Preacher, K. J., \& Hayes, A. F. (2008). Asymptotic and Resampling Strategies for Assessing and Comparing Indirect Effects in Multiple Mediator Models. Behavior Research Methods, 40(3), 879-891.

57. Richter, B., Schularick, M., \& Shim, I. (2019). The costs of macroprudential policy. Journal of International Economics, 118, 263-282,

58. Roger, S. (2010). Inflation Targeting Turns 20. Finance \& Development, 47(1), 46-49.

59. Roodman, D. (2009a). A note on the theme of too many instruments. Oxford Bulletin of Economics and statistics, 71(1), 135-158.

60. Roodman, D. (2009b). How to do xtabond2: an introduction to difference and system GMM in Stata. Stata Journal, 9(1), 86-136.

61. Samimi, Ahmad J., Ghaderi, S., Hosseinzadeh, R., \& Nademi, Y. (2012). Openness and inflation: New empirical panel data evidence. Economics Letters, 117(3), 573-577. 
62. Sotomska-Krzysztofik, O., \& Szczepanska, O. (2006). Transparency of Central Banks in Supporting Financial Stability. Banks and Bank Systems, 1(3), 20-31.

63. Svensson, Lars E. O. (2010). Inflation targeting. Chapter 22, Handbook of Monetary Economics, 3, 1237-1302.

64. Tayler, W., \& Zilberman, R. (2014). Macroprudential Regulation and the Role of Monetary Policy. Dynare Working Papers Series n³7. Available at: https://www.dynare.org/wp-repo/dynarewp037.pdf

65. Temple, J. (1998). Central bank independence and inflation: good news and bad news. Economics Letters, 61(2), 215-219.

66. Tillmann, P. (2015). Estimating the Effects of Macroprudential Policy Shocks: A Qual VAR Approach. Economics Letters, 135, 1 - 4.

67. Trabelsi, E. (2016). What effects exert Economic Globalization and Central Bank Transparency on inflation of OECD countries? An Application of LSDVC Estimator on a dynamic Panel Model. Economics Bulletin, 10951126.

68. van der Cruijsen, C. A.B., Eijffinger, S. C.W., \& Hoogduin, L. H. (2010). Optimal Central Bank Transparency. Journal of International Money and Finance, 29(8), 1482-1507.

69. van der Cruijsen, C. A.B., \& Demertzis, M (2007). The impact of central bank transparency on inflation expectations. European Journal of Political Economy, 23(1), 51-66.

70. Windmeijer, F. (2005). A finite sample correction for the variance of linear efficient two-step GMM estimators. Journal of Econometrics, 126(1), 25-51.

71. Zhao, X., Lynch, J. G., \& Chen, Q. (2010). Reconsidering Baron and Kenny: Myths and Truths about Mediation Analysis. Journal of Consumer Research, 37(2), 197-206. 


\section{Appendix A}

Table A.1: Effect of macroprudential transparency on banking crisis: Logistic regression with fixed effects

\begin{tabular}{|c|c|c|c|c|c|c|c|}
\hline & \multicolumn{7}{|c|}{ Path (a) } \\
\hline & (1) & (2) & (3) & (4) & (5) & (6) & (7) \\
\hline $\mathrm{MPT}_{\text {it }}$ & $\begin{array}{c}-0.492^{* *} \\
(0.192)\end{array}$ & $\begin{array}{l}-0.350^{*} \\
(0.208)\end{array}$ & $\begin{array}{l}-0.269 \\
(0.241)\end{array}$ & $\begin{array}{l}-0.380^{*} \\
(0.209)\end{array}$ & $\begin{array}{l}-0.355^{*} \\
(0.212)\end{array}$ & $\begin{array}{l}-0.404^{*} \\
(0.224)\end{array}$ & $\begin{array}{c}-0.350^{*} \\
(0.210)\end{array}$ \\
\hline GDP per capita (in log) & $\begin{array}{l}1.726^{* * *} \\
(0.515)\end{array}$ & $\begin{array}{l}1.667^{* * *} \\
(0.559)\end{array}$ & $\begin{array}{l}1.784^{* * * *} \\
(0.619)\end{array}$ & $\begin{array}{l}1.690^{* * *} \\
(0.570)\end{array}$ & $\begin{array}{l}1.581^{* * *} \\
(0.545)\end{array}$ & $\begin{array}{l}1.814^{* * * *} \\
(0.616)\end{array}$ & $\begin{array}{l}1.624^{* * * *} \\
(0.562)\end{array}$ \\
\hline $\mathrm{FO}_{\mathrm{it}}$ & $\begin{array}{c}0.189 \\
(0.437)\end{array}$ & $\begin{array}{l}0.0827 \\
(0.476)\end{array}$ & $\begin{array}{l}0.0846 \\
(0.565)\end{array}$ & $\begin{array}{c}0.163 \\
(0.495)\end{array}$ & $\begin{array}{r}-0.0539 \\
(0.539)\end{array}$ & $\begin{array}{c}0.536 \\
(0.569)\end{array}$ & $\begin{array}{l}0.0198 \\
(0.479)\end{array}$ \\
\hline Trade $_{\text {it }}$ & $\begin{array}{c}0.00984 \\
(0.022)\end{array}$ & $\begin{array}{c}-0.000805 \\
(0.024)\end{array}$ & $\begin{array}{c}0.00456 \\
(0.026)\end{array}$ & $\begin{array}{c}0.000337 \\
(0.024)\end{array}$ & $\begin{array}{l}0.00747 \\
(0.025)\end{array}$ & $\begin{array}{c}-0.0238 \\
(0.026)\end{array}$ & $\begin{array}{c}-0.00187 \\
(0.024)\end{array}$ \\
\hline$P S_{i t}$ & & $\begin{array}{l}-0.913 \\
(0.946)\end{array}$ & & & & & \\
\hline $\mathrm{CC}_{\mathrm{it}}$ & & & $\begin{array}{c}-5.748^{* * *} \\
(1.674)\end{array}$ & & & & \\
\hline $\mathrm{RL}_{\mathrm{it}}$ & & & & $\begin{array}{l}-0.748 \\
(1.732)\end{array}$ & & & \\
\hline $\mathrm{RQ}_{\mathrm{it}}$ & & & & & $\begin{array}{c}0.947 \\
(1.602)\end{array}$ & & \\
\hline $\mathrm{GE}_{\mathrm{it}}$ & & & & & & $\begin{array}{c}-7.407^{* * * *} \\
(2.301)\end{array}$ & \\
\hline$V A_{i t}$ & & & & & & & $\begin{array}{l}-1.878 \\
(1.539) \\
\end{array}$ \\
\hline Noobservations & 156 & 143 & 143 & 143 & 143 & 143 & 143 \\
\hline Hausman & 42.1 & 20.37 & 17.87 & 21.56 & 65.83 & 38.76 & 20.01 \\
\hline Hausman ( $p$-value) & 0.000 & 0.0011 & 0.0031 & 0.0006 & 0.0000 & 0.0000 & 0.0012 \\
\hline
\end{tabular}

Standard errors in parentheses. ${ }^{*} \mathrm{p}<0.1,{ }^{* *} \mathrm{p}<0.05,{ }^{* * *} \mathrm{p}<0.01$ 
Table A.2: Effect of macroprudential transparency on inflation: Non-inflation targeting countries

\begin{tabular}{|c|c|c|c|c|c|c|c|}
\hline & \multicolumn{7}{|c|}{ Without mediator: Path (c) } \\
\hline & (1) & (2) & (3) & (4) & (5) & (6) & (7) \\
\hline Inflation $_{\mathrm{it-1}}$ & $\begin{array}{c}0.359^{* * *} \\
(0.031)\end{array}$ & $\begin{array}{c}0.334^{* * *} \\
(0.018)\end{array}$ & $\begin{array}{l}0.407^{* * *} \\
(0.031)\end{array}$ & $\begin{array}{l}0.365^{* * *} \\
(0.058)\end{array}$ & $\begin{array}{c}0.359^{* * * *} \\
(0.052)\end{array}$ & $\begin{array}{l}0.372^{* * *} \\
(0.047)\end{array}$ & $\begin{array}{c}0.349^{* * *} \\
(0.037)\end{array}$ \\
\hline $\mathrm{MPT}_{\mathrm{it}-1}$ & $\begin{array}{l}-0.745^{*} \\
(0.424)\end{array}$ & $\begin{array}{l}-1.294^{* *} \\
(0.636)\end{array}$ & $\begin{array}{l}-1.032^{*} \\
(0.624)\end{array}$ & $\begin{array}{c}-0.889^{* *} \\
(0.431)\end{array}$ & $\begin{array}{l}-0.690^{*} \\
(0.357)\end{array}$ & $\begin{array}{l}-0.626 \\
(0.389)\end{array}$ & $\begin{array}{c}-1.008^{* *} \\
(0.449)\end{array}$ \\
\hline Real GDP per capita ${ }_{\mathrm{it}-1}(\mathrm{log})$ & & & $\begin{array}{l}-0.526 \\
(1.405)\end{array}$ & $\begin{array}{l}-3.813 \\
(7.030)\end{array}$ & $\begin{array}{l}-1.393 \\
(4.435)\end{array}$ & $\begin{array}{l}-0.285 \\
(1.794)\end{array}$ & $\begin{array}{l}-0.107 \\
(1.999)\end{array}$ \\
\hline Government consumption $\mathrm{it}_{\mathrm{it}-1}$ & $\begin{array}{c}0.055 \\
(0.234)\end{array}$ & & & & & & \\
\hline External debt/GNI ${ }_{\mathrm{ut}-1}$ & & $\begin{array}{c}0.015 \\
(0.013)\end{array}$ & & & & & \\
\hline \multicolumn{8}{|l|}{ 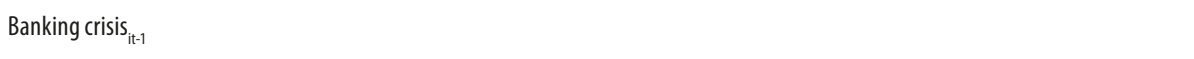 } \\
\hline $\mathrm{CBI}_{\text {it }}$ & & & $\begin{array}{c}2.640 \\
(2.812)\end{array}$ & & & & \\
\hline Trade $_{\text {it }}$ & $\begin{array}{c}0.032 \\
(0.021)\end{array}$ & $\begin{array}{c}0.009 \\
(0.017)\end{array}$ & & $\begin{array}{c}0.023 \\
(0.076)\end{array}$ & $\begin{array}{c}0.007 \\
(0.047)\end{array}$ & $\begin{array}{l}-0.002 \\
(0.046)\end{array}$ & $\begin{array}{l}-0.011 \\
(0.052)\end{array}$ \\
\hline $\mathrm{PS}_{\mathrm{it}-1}$ & $\begin{array}{c}-4.343^{* * *} \\
(0.836)\end{array}$ & $\begin{array}{c}-3.761^{* * * *} \\
(1.049)\end{array}$ & & & $\begin{array}{l}-1.203 \\
(1.367)\end{array}$ & & \\
\hline $\mathrm{RL}_{\mathrm{it}-1}$ & & & & & & $\begin{array}{l}-1.569 \\
(2.661)\end{array}$ & \\
\hline$C_{i t-1}$ & & & & & & & $\begin{array}{l}-1.781 \\
(4.281)\end{array}$ \\
\hline Constant & $\begin{array}{l}0.000 \\
(.)\end{array}$ & $\begin{array}{c}1.867 \\
(2.140)\end{array}$ & $\begin{array}{c}12.925 \\
(12.273)\end{array}$ & $\begin{array}{c}32.883 \\
(50.948)\end{array}$ & $\begin{array}{c}14.904 \\
(33.008)\end{array}$ & $\begin{array}{c}6.141 \\
(11.508)\end{array}$ & $\begin{array}{c}5.254 \\
(13.535)\end{array}$ \\
\hline Noobservations & 656 & 482 & 752 & 738 & 670 & 672 & 672 \\
\hline$N^{\circ}$ countries & 70 & 52 & 70 & 71 & 71 & 71 & 71 \\
\hline$N^{\circ}$ instruments & 62 & 49 & 64 & 60 & 63 & 65 & 58 \\
\hline AR1 (p-value) & 0.025 & 0.038 & 0.004 & 0.008 & 0.022 & 0.021 & 0.021 \\
\hline AR2 (p-value) & 0.405 & 0.260 & 0.860 & 0.516 & 0.615 & 0.617 & 0.758 \\
\hline Hansen test ( $p$-value) & 0.244 & 0.667 & 0.115 & 0.308 & 0.109 & 0.084 & 0.101 \\
\hline
\end{tabular}




\begin{tabular}{|c|c|c|c|c|c|c|}
\hline & \multicolumn{6}{|c|}{ With mediator: Paths (b) and ( $\left.c^{\prime}\right)$} \\
\hline & (8) & (9) & (10) & (11) & (12) & (13) \\
\hline Inflation $_{\text {it-1 }}$ & $\begin{array}{l}0.375^{* * *} \\
(0.028)\end{array}$ & $\begin{array}{l}0.407^{* * *} \\
(0.028)\end{array}$ & $\begin{array}{c}0.387^{* * *} \\
(0.045)\end{array}$ & $\begin{array}{l}0.361^{* * *} \\
(0.055)\end{array}$ & $\begin{array}{l}0.334^{* * *} \\
(0.054)\end{array}$ & $\begin{array}{l}0.348^{* * *} \\
(0.054)\end{array}$ \\
\hline $\mathrm{MPT}_{\mathrm{it}-1}$ & $\begin{array}{l}-0.628^{*} \\
(0.379)\end{array}$ & $\begin{array}{l}-0.774^{*} \\
(0.450)\end{array}$ & $\begin{array}{l}-0.379 \\
(0.283)\end{array}$ & $\begin{array}{l}-0.495 \\
(0.430)\end{array}$ & $\begin{array}{l}-0.737^{* *} \\
(0.356)\end{array}$ & $\begin{array}{c}-0.787^{* *} \\
(0.370)\end{array}$ \\
\hline Real GDP per capita ${ }_{\mathrm{it}-1}(\log )$ & & $\begin{array}{l}-0.387 \\
(1.021)\end{array}$ & $\begin{array}{l}-2.351 \\
(2.301)\end{array}$ & $\begin{array}{l}-3.489 \\
(3.913)\end{array}$ & $\begin{array}{l}-0.178 \\
(1.681)\end{array}$ & $\begin{array}{l}-0.791 \\
(2.344)\end{array}$ \\
\hline$G$ overnment consumption ${ }_{\mathrm{it}-1}$ & $\begin{array}{l}-0.173 \\
(0.226)\end{array}$ & & & & & \\
\hline \multicolumn{7}{|l|}{ External debt/GNI ${ }_{\mathrm{ut}-1}$} \\
\hline 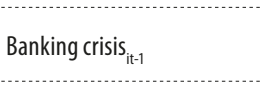 & $\begin{array}{c}4.715 \\
(3.829)\end{array}$ & $\begin{array}{l}8.209^{*} \\
(4.506)\end{array}$ & $\begin{array}{c}7.767^{*} \\
(4.095)\end{array}$ & $\begin{array}{l}5.054^{*} \\
(2.985)\end{array}$ & $\begin{array}{c}5.81^{0^{*}} \\
(3.519)\end{array}$ & $\begin{array}{l}5.267^{*} \\
(3.138)\end{array}$ \\
\hline $\mathrm{CBI}_{\text {it }}$ & & $\begin{array}{l}-0.218 \\
(2.536)\end{array}$ & & & & \\
\hline Trade $_{\text {it }}$ & $\begin{array}{c}0.040 \\
(0.026)\end{array}$ & & $\begin{array}{c}0.019 \\
(0.033)\end{array}$ & $\begin{array}{c}0.025 \\
(0.040)\end{array}$ & $\begin{array}{c}0.006 \\
(0.036)\end{array}$ & $\begin{array}{c}0.009 \\
(0.052)\end{array}$ \\
\hline$P S_{i t-1}$ & $\begin{array}{c}-3.614^{* * *} \\
(1.315)\end{array}$ & & & $\begin{array}{l}-0.397 \\
(1.331)\end{array}$ & & \\
\hline $\mathrm{RL}_{\mathrm{it}-1}$ & & & & & $\begin{array}{l}-2.747 \\
(3.531)\end{array}$ & \\
\hline$C_{i t-1}$ & & & & & & $\begin{array}{l}-1.815 \\
(2.851)\end{array}$ \\
\hline Constant & $\begin{array}{c}3.045 \\
(3.799) \\
\end{array}$ & $\begin{array}{c}6.636 \\
(9.278) \\
\end{array}$ & $\begin{array}{l}23.653 \\
(17.499) \\
\end{array}$ & $\begin{array}{c}31.382 \\
(30.510) \\
\end{array}$ & $\begin{array}{c}2.845 \\
(13.241)\end{array}$ & $\begin{array}{c}9.155 \\
(15.737) \\
\end{array}$ \\
\hline Noobservations & 656 & 752 & 738 & 670 & 672 & 672 \\
\hline $\mathrm{N}^{\circ}$ countries & 70 & 70 & 71 & 71 & 71 & 71 \\
\hline $\mathrm{N}^{\circ}$ instruments & 67 & 66 & 75 & 67 & 65 & 64 \\
\hline AR1 (p-value) & 0.023 & 0.004 & 0.007 & 0.020 & 0.021 & 0.020 \\
\hline AR2 ( $p$-value) & 0.615 & 0.777 & 0.545 & 0.703 & 0.833 & 0.774 \\
\hline Hansen test ( $p$-value) & 0.332 & 0.175 & 0.261 & 0.168 & 0.109 & 0.121 \\
\hline
\end{tabular}

Robust standard errors in parentheses

${ }^{*} \mathrm{p}<0.1,{ }^{* *} \mathrm{p}<0.05,{ }^{* * *} \mathrm{p}<0.01$

Inflation: inflation rate, MPT: the index of macroprudential transparency, Real GDP per capita (log): The natural logarithm of real GDP per capita, Government consumption: Government consumption as a share of GDP, External debt: the ratio of external debt to GNI, banking crisis: a dummy that takes one if a crisis occurs in a country and 0 otherwise, Trade: The share of imports and exports to GDP, CBI: central bank independence index of Garriga (2016), PS: political stability, RL: rule of law and CC: control of corruption. AR1, AR2 are the first-order and the second order serial correlation and Hansen is the test of overidentifying restrictions. 
Table A.3: Effect of macroprudential transparency on inflation, GDP deflator: Non-inflation targeting countries

\begin{tabular}{|c|c|c|c|c|c|c|c|c|c|c|}
\hline & \multicolumn{4}{|c|}{ Without mediator: Path (c) } & \multicolumn{6}{|c|}{ With mediators: Paths (b) and $\left(c^{\prime}\right)$} \\
\hline & (1) & (2) & (3) & (4) & (5) & (6) & (7) & (8) & (9) & $(10)$ \\
\hline $\begin{array}{l}\text { Inflation_GDP } \\
\text { deflator }\end{array}$ & $\begin{array}{l}0.289^{* * *} \\
(0.098)\end{array}$ & $\begin{array}{l}0.241^{*} \\
(0.127)\end{array}$ & $\begin{array}{l}0.261^{* * *} \\
(0.098)\end{array}$ & $\begin{array}{l}0.246^{* *} \\
(0.109)\end{array}$ & $\begin{array}{l}0.269^{* *} \\
(0.136)\end{array}$ & $\begin{array}{c}0.317^{* * *} \\
(0.100)\end{array}$ & $\begin{array}{l}0.298^{* *} \\
(0.119)\end{array}$ & $\begin{array}{l}0.249^{*} \\
(0.139)\end{array}$ & $\begin{array}{c}0.182 \\
(0.134)\end{array}$ & $\begin{array}{l}0.216^{*} \\
(0.128)\end{array}$ \\
\hline $\mathrm{MPT}_{\mathrm{it}-1}$ & $\begin{array}{l}-1.977^{* *} \\
(0.917)\end{array}$ & $\begin{array}{c}-2.310^{* *} \\
(1.033)\end{array}$ & $\begin{array}{l}-1.525^{*} \\
(0.926)\end{array}$ & $\begin{array}{l}-1.370^{*} \\
(0.748)\end{array}$ & $\begin{array}{l}-1.233^{* *} \\
(0.607)\end{array}$ & $\begin{array}{l}-1.376 \\
(1.004)\end{array}$ & $\begin{array}{l}-1.923^{*} \\
(1.003)\end{array}$ & $\begin{array}{c}-1.635^{* *} \\
(0.813)\end{array}$ & $\begin{array}{l}-1.443^{* *} \\
(0.567)\end{array}$ & $\begin{array}{l}-1.301^{*} \\
(0.683)\end{array}$ \\
\hline $\begin{array}{l}\text { Real GDP per } \\
\text { capita }_{\text {it-1 }} \text { (log) }\end{array}$ & & $\begin{array}{c}1.880 \\
(1.838)\end{array}$ & $\begin{array}{l}2.219^{* *} \\
(1.110)\end{array}$ & $\begin{array}{c}1.624 \\
(1.455)\end{array}$ & & $\begin{array}{c}0.001 \\
(1.191)\end{array}$ & $\begin{array}{l}-0.961 \\
(1.220)\end{array}$ & $\begin{array}{l}-0.003 \\
(2.009)\end{array}$ & $\begin{array}{c}0.234 \\
(1.579) \\
\end{array}$ & $\begin{array}{r}0.266 \\
(1.747) \\
\end{array}$ \\
\hline $\begin{array}{l}\text { Government } \\
\text { consumption }\end{array}$ & $\begin{array}{l}-0.137 \\
(0.408)\end{array}$ & & & & $\begin{array}{l}0.091 \\
(0.401)\end{array}$ & & & & & \\
\hline 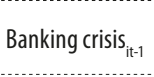 & & & & & $\begin{array}{l}13.726^{*} \\
(6.713)\end{array}$ & $\begin{array}{c}10.360^{* *} \\
(5.234)\end{array}$ & $\begin{array}{l}10.213^{*} \\
(5.586)\end{array}$ & $\begin{array}{l}11.278^{*} \\
(6.515)\end{array}$ & $\begin{array}{l}11.356 \\
(6.947)\end{array}$ & $\begin{array}{r}3.529 \\
(6.867)\end{array}$ \\
\hline Trade $_{\text {it }}$ & $\begin{array}{c}0.027 \\
(0.033)\end{array}$ & $\begin{array}{l}-0.008 \\
(0.040)\end{array}$ & $\begin{array}{l}-0.020 \\
(0.030)\end{array}$ & $\begin{array}{l}-0.009 \\
(0.037)\end{array}$ & $\begin{array}{l}0.032 \\
(0.035)\end{array}$ & $\begin{array}{l}-0.022 \\
(0.024)\end{array}$ & $\begin{array}{l}-0.013 \\
(0.023)\end{array}$ & $\begin{array}{c}0.028 \\
(0.037)\end{array}$ & $\begin{array}{c}0.027 \\
(0.033)\end{array}$ & $\begin{array}{c}0.029 \\
(0.033)\end{array}$ \\
\hline $\mathrm{CBI}_{\text {it }}$ & & & & & & $\begin{array}{c}1.525 \\
(4.472) \\
\end{array}$ & & & & \\
\hline$P S_{i t-1}$ & $\begin{array}{l}-5.723^{* *} \\
(2.457)\end{array}$ & $\begin{array}{l}-5.530^{* *} \\
(2.298)\end{array}$ & & & $\begin{array}{l}-4.918^{* *} \\
(1.977)\end{array}$ & & & $\begin{array}{c}-4.747^{* * * *} \\
(1.726)\end{array}$ & & \\
\hline $\mathrm{RL}_{\mathrm{it}-1}$ & & & $\begin{array}{l}-5.156^{*} \\
(3.025)\end{array}$ & & & & & & $\begin{array}{l}-7.251^{*} \\
(2.822)\end{array}$ & \\
\hline$C_{i t-1}$ & & & & $\begin{array}{l}-6.004^{*} \\
(3.598)\end{array}$ & & & & & & $\begin{array}{r}-9.335^{* *} \\
(3.530)\end{array}$ \\
\hline Constant & $\begin{array}{c}1.910 \\
(7.347) \\
\end{array}$ & $\begin{array}{l}-10.068 \\
(13.093) \\
\end{array}$ & $\begin{array}{l}-4.047 \\
(9.198) \\
\end{array}$ & $\begin{array}{l}-13.039 \\
(10.927) \\
\end{array}$ & $\begin{array}{c}0.343 \\
(7.724) \\
\end{array}$ & $\begin{array}{c}4.608 \\
(9.551) \\
\end{array}$ & $\begin{array}{c}8.991 \\
(9.936) \\
\end{array}$ & $\begin{array}{c}1.043 \\
(14.828) \\
\end{array}$ & $\begin{array}{c}4.364 \\
(13.057) \\
\end{array}$ & $\begin{array}{c}-1.621 \\
(12.480) \\
\end{array}$ \\
\hline Noobservations & 681 & 698 & 700 & 700 & 681 & 753 & 769 & 698 & 700 & 700 \\
\hline Nocountries & 73 & 73 & 73 & 73 & 73 & 72 & 73 & 73 & 73 & 73 \\
\hline Noinstruments & 67 & 65 & 65 & 64 & 76 & 72 & 66 & 79 & 74 & 66 \\
\hline AR1 ( $p$-value) & 0.006 & 0.009 & 0.005 & 0.007 & 0.007 & 0.003 & 0.005 & 0.008 & 0.009 & 0.009 \\
\hline AR2 (p-value) & 0.636 & 0.718 & 0.651 & 0.783 & 0.762 & 0.249 & 0.299 & 0.726 & 0.864 & 0.849 \\
\hline $\begin{array}{l}\text { Hansen test } \\
\text { (p-value) }\end{array}$ & 0.198 & 0.109 & 0.221 & 0.159 & 0.241 & 0.143 & 0.133 & 0.269 & 0.182 & 0.112 \\
\hline
\end{tabular}

Robust standard errors in parentheses

${ }^{*} \mathrm{p}<0.1,{ }^{* *} \mathrm{p}<0.05,{ }^{* * *} \mathrm{p}<0.01$

Inflation_GDP deflator: inflation, GDP deflator, MPT: the index of macroprudential transparency, Real GDP per capita (log): The natural logarithm of real GDP per capita, Government consumption: Government consumption as a share of GDP, banking crisis: a dummy that takes one if a crisis occurs in a country and 0 otherwise, Trade: The share of imports and exports to GDP, CBI: central bank independence index of Garriga (2016), PS: political stability, RL: rule of law and CC: control of corruption.

AR1, AR2 are the first-order and the second order serial correlation and Hansen is the test of overidentifying restrictions. 
Table A.4: Cross-sectional mediation analysis (Non-inflation targeting countries)

Dependent variable: Inflation

Mediator: Banking crisis

Predictor: Macroprudential transparency

Bootstrap results

Number of obs $\quad=\quad 78$

Replications $\quad 5000$

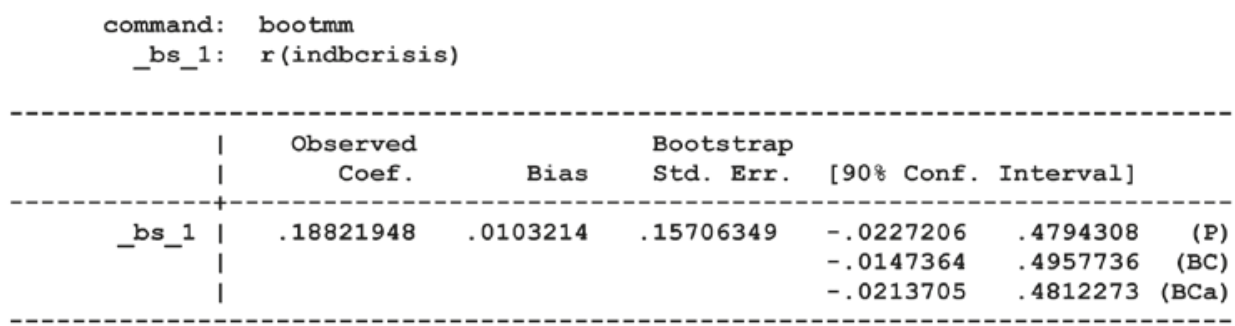

(P) percentile confidence interval

(BC) bias-corrected confidence interval

(BCa) bias-corrected and accelerated confidence interval

indbcrisis: The indirect effect of macroprudential transparency on inflation through banking crisis.

\section{Table A.4: Cont.}

Dependent variable: Inflation, GDP deflator

Mediator: Banking crisis

Predictor: Macroprudential transparency

Bootstrap results

Number of obs

81

Botstrap results

Replications

$=$

$=\quad 5000$

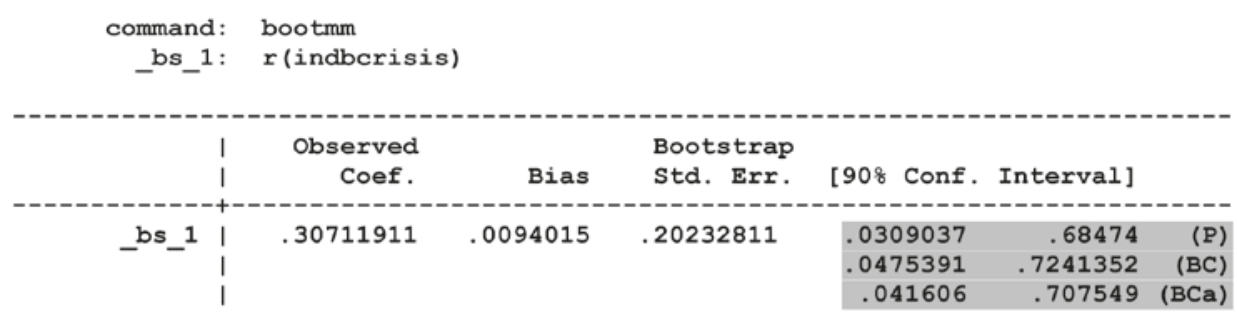

(P) percentile confidence interval

(BC) bias-corrected confidence interval

(BCa) bias-corrected and accelerated confidence interval

indberisis: The indirect effect of macroprudential transparency on inflation, GDP deflator through banking crisis. 